\title{
Synonymy of Candida methylica with Candida boidinii and of Candida methanolophaga with Candida succiphila
}

\author{
CHING-FU LEE, $\dagger$ FWU-LING LEE, ${ }^{*}$ AND WEN-HAW HSU \\ Food Industry Research and Development Institute, Hsinchu 300, Taiwan, Republic of China
}

\begin{abstract}
Some Candida species which can use methanol as a sole carbon source were studied by performing chemotaxonomic tests; we determined the ubiquinone systems of these organisms, their DNA base compositions, their electrophoretic karyotypes, and their DNA relatedness values. The type strains of Candida methanolophaga and Candida succiphila had similar DNA base compositions and exhibited 90\% DNA relatedness. All Candida boidinii and Candida methylica strains had DNA G+C contents of 30.8 to $31.0 \mathrm{~mol} \%$, and these organisms exhibited 87 to $101 \%$ DNA relatedness to the type strain of $C$. boidinii. We propose that $C$. methanolophaga and $C$. methylica should be synonyms of $C$. succiphila and $C$. boidinii, respectively.
\end{abstract}

Identification of methanol-assimilating yeasts is based on several characteristics, including DNA base composition, ubiquinone system, proton magnetic resonance spectra of cell wall mannans, and electrophoretic patterns of enzymes $(8$, 10-12). Several new methanol-assimilating Candida species have been described, including Candida methylica (17), Candida cariosilignicola and Candida succiphila (11), Candida methanolophaga (9), and Candida nanaspora (14). Among these species, $C$. cariosilignicola and $C$. nanaspora can be easily differentiated from other Candida species on the basis of physiological characteristics, while $C$. methanolophaga and $C$. methylica differ from $C$. succiphila and $C$. boidinii, respectively, in only a few phenotypic characteristics (1).

In this study, we compared the electrophoretic karyotypes and DNA base compositions of strains belonging to several methylotrophic Candida species. In addition, we investigated the levels of DNA relatedness between pairs of strains to verify the relationships among the Candida species studied.

Ten strains belonging to nine Candida species were used in this study. The sources of these strains are shown in Table 1. Morphological and physiological characteristics were investigated by the methods described by van der Walt and Yarrow (18).
To determine ubiquinone systems, cells were grown in the liquid medium of Billon-Grand (2) and were collected at the early stationary phase of the growth. The ubiquinones were extracted and purified by the method of Collins et al. (4). The purified quinones were analyzed by high-performance liquid chromatography (HPLC).

In addition, all of the strains examined were grown in YM (0.3\% yeast extract, $0.3 \%$ malt extract, $0.5 \%$ Bacto-Peptone, $1 \%$ glucose; Difco) agar slants at $25^{\circ} \mathrm{C}$ for 1 to 2 days. The cells were harvested, washed twice with $0.05 \mathrm{M}$ EDTA ( $\mathrm{pH} 7.5$ ), and then used to prepare agarose blocks as described by Carle and Olson (3). Electrophoresis was performed by using a contourclamped homogeneous electric field system with a hexagonal electrode array (Bio-Rad Laboratories) as described by Vollrath and Davis (19).

For DNA studies cells were grown in YM broth and harvested in the late exponential phase of growth. DNA was isolated and purified by the method of Kaneko and Banno (7). Each purified DNA was hydrolyzed to nucleosides as described by Tamaoka and Komagata (16), and the hydrolysate was analyzed by reverse-phase HPLC to determine its DNA base composition $(\mathrm{G}+\mathrm{C}$ content). Levels of DNA relatedness were determined by the photobiotin labeling microplate method, as

TABLE 1. Yeast strains studied

\begin{tabular}{|c|c|c|c|}
\hline \multirow{2}{*}{ Species } & \multicolumn{2}{|c|}{ Strain designations ${ }^{a}$} & \multirow{2}{*}{ Source } \\
\hline & CCRC & CBS & \\
\hline Candida boidinii Ramirez 1953 & $20464^{\mathrm{T}}$ & $2428^{\mathrm{T}}$ & Tanning liquor \\
\hline Candida boidinii & 21758 & 8051 & Soil \\
\hline Candida cariosilignicola Lee et Komagata 1980 & $21405^{\mathrm{T}}$ & $8001^{\mathrm{T}}$ & Decayed timber \\
\hline Candida methanolophaga Kumamoto et Yamamoto 1986 & $22418^{\mathrm{T}}$ & $7297^{\mathrm{T}}$ & Oil field \\
\hline Candida methylica Trotsenko et Bykovskaya 1974 & $21757^{\mathrm{T}}$ & $8030^{\mathrm{T}}$ & Soil \\
\hline Candida nanaspora Saëz et Rodrigues de Miranda 1988 & $22419^{\mathrm{T}}$ & $7200^{\mathrm{T}}$ & Male ape \\
\hline Candida nitratophila Meyer et Yarrow 1978 & $21583^{\mathrm{T}}$ & $2027^{\mathrm{T}}$ & Bark beetle \\
\hline Candida pignaliae Meyer et Yarrow 1978 & $21625^{\mathrm{T}}$ & $6071^{\mathrm{T}}$ & Tanning liquor \\
\hline Candida pinus Meyer et Yarrow 1978 & $22437^{\mathrm{T}}$ & $970^{\mathrm{T}}$ & Pine \\
\hline Candida succiphila Lee et Komagata 1980 & $21410^{\mathrm{T}}$ & $8003^{\mathrm{T}}$ & Sap of peach tree \\
\hline
\end{tabular}

${ }^{a}$ CCRC, Culture Collection and Research Center, Food Industry Research and Development Institute, Taiwan, Republic of China; CBS, Centraalbureau voor Schimmelcultures, Delft, The Netherlands.

\footnotetext{
* Corresponding author. Mailing address: Food Industry Research and Development Institute, P.O. Box 246, Hsinchu 300, Taiwan, Republic of China. Phone: 886-35-223191. Fax: 886-35-214016.

$\dagger$ Present address: Yuanpei Junior College of Medical Technology, Hsinchu 300, Taiwan, Republic of China.
} 
TABLE 2. Selected phenotypic characteristics of the Candida strains studied

\begin{tabular}{|c|c|c|c|c|c|c|c|c|c|c|c|c|c|c|c|c|}
\hline \multirow[b]{2}{*}{ Strain } & \multicolumn{5}{|c|}{ Fermentation of: } & \multicolumn{10}{|c|}{ Assimilation of: } & \multirow[b]{2}{*}{$\begin{array}{l}\text { Growth } \\
\text { at } 37^{\circ} \mathrm{C}\end{array}$} \\
\hline & $\frac{\mathscr{Z}}{8}$ & 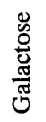 & 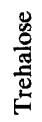 & 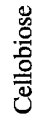 & 兽 & 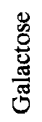 & 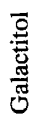 & 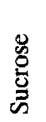 & 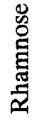 & 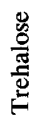 & 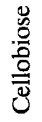 & 苞 & 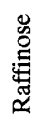 & $\begin{array}{l}0 \\
: \\
: 0 \\
0\end{array}$ & $\underset{Z}{\stackrel{\Xi}{*}}$ & \\
\hline C. boidinii CCRC $20464^{\mathrm{T}}$ & $+^{a}$ & - & - & - & - & - & - & - & - & - & - & - & - & + & + & - \\
\hline C. boidinii CCRC 21758 & + & - & - & - & - & - & - & - & - & - & - & - & - & + & + & - \\
\hline C. methylica CCRC $21757^{\mathrm{T}}$ & + & - & - & - & - & - & - & - & + & - & - & - & - & - & + & - \\
\hline C. methanolophaga CCRC $22418^{\mathrm{T}}$ & + & + & + & + & - & + & - & - & + & + & + & - & - & + & - & $\mathbf{w}$ \\
\hline C. succiphila CCRC $21410^{\mathbf{T}}$ & + & + & + & + & - & + & + & - & + & + & + & + & - & + & - & + \\
\hline C. cariosilignicola CCRC $21405^{\mathrm{T}}$ & + & - & + & - & + & - & - & + & + & + & - & - & + & + & + & + \\
\hline C. nanaspora CCRC $22419^{\mathrm{T}}$ & + & + & + & - & - & + & - & - & + & + & - & - & - & + & + & + \\
\hline C. nitratophila CCRC $21583^{\mathrm{T}}$ & + & + & + & - & - & + & - & - & + & + & - & - & - & + & + & - \\
\hline C. pignaliae CCRC $21625^{\mathrm{T}}$ & + & - & + & - & - & - & - & - & - & + & - & - & - & - & + & - \\
\hline C. pinus CCRC $22437^{\mathrm{T}}$ & + & - & + & - & - & - & - & - & - & + & - & - & - & + & - & - \\
\hline
\end{tabular}

$a+$, positive; - , negative.

modified by Kaneko and Banno (7) from the method of Ezaki et al. $(5,6)$. The main modification was as follows: $400 \mathrm{ng}$ of heat-denatured yeast DNA was immobilized in a well of a microplate at $28^{\circ} \mathrm{C}$ overnight, and hybridization was performed at $42^{\circ} \mathrm{C}$ for $24 \mathrm{~h}$.

The phenotypic characteristics which we determined were the same as those described in the monograph of Barnett et al. (1). On the basis of the results of our phenotypic characterization of Candida species we identified three groups; group I contained C. boidinii and C. methylica, group II contained $C$. methanolophaga and $C$. succiphila, and group III contained Candida pignaliae, Candida pinus, Candida nitratophila, and Candida nanaspora. Selected phenotypic characteristics are shown in Table 2. The phenotypic characteristics of the members of each group were quite similar. C. methanolophaga and $C$. succiphila differed only in assimilation of galactitol and DL-lactate and growth at $37^{\circ} \mathrm{C}$, whereas $C$. boidinii and $C$. methylica differed only in assimilation of D-ribose and $\mathrm{L}^{-}$ rhamnose.

All strains of the Candida species which we studied had Q-7 as the major component of the ubiquinone system (Table 3 ), as reported previously $(8,10-12)$.

The chromosomal DNA banding patterns of the Candida species studied were examined by pulsed-field gel electrophoresis (Fig. 1). In group I ( $C$. boidinii and $C$. methylica) the electrophoretic karyotypes of the two strains of $C$. boidinii exhibited polymorphisms in chromosomal DNA size and band number (Fig. 1, lanes 2 and 3). This is probably an example of chromosome length polymorphism, which has also been reported for Saccharomyces cerevisiae (3), and Kluyveromyces spp. (15). The pattern of $C$. methylica CCRC $21757^{\mathrm{T}}(\mathrm{T}=$ type strain) was rather similar to that of $C$. boidinii CCRC 21758, but differed in DNA band number from the pattern of $C$. boidinii CCRC $20464^{\mathrm{T}}$. In group II, $C$. methanolophaga and $C$. succiphila (lanes 8 and 9) produced identical chromosomal DNA patterns; it was obvious that these two species are closely related. In group III, every species produced a distinct chromosomal band pattern.

The DNA base compositions of the Candida species studied are shown in Table 3 . The DNA $\mathrm{G}+\mathrm{C}$ contents of the group I species $C$. boidinii and $C$. methylica were 30.8 to $31.0 \mathrm{~mol} \%$, and the DNA $\mathrm{G}+\mathrm{C}$ contents of the group II species $C$. methanolophaga and C. succiphila were 39.5 and $40.0 \mathrm{~mol} \%$, respectively. Our values were somewhat lower than the values determined previously by the thermal denaturation method ( 1 , $8,9,11)$. In group III, the DNA base compositions of the species described in the references cited by Barnett et al. (1) ranged from 35.1 to $42.7 \mathrm{~mol} \%$.

Levels of DNA relatedness were determined by the microplate hybridization method (5-7), and the results are shown in Table 3. The DNAs of the type strains of $C$. boidinii, $C$. succiphila, and $C$. pinus were labeled with photobiotin to determine their levels of relatedness to other DNAs. In group I, C. boidinii CCRC 21758 and C. methylica exhibited high levels ( 87 to $101 \%$ ) of DNA relatedness to the type strain of $C$. boidinii; it was obvious that there is a close relationship

TABLE 3. Major ubiquinones, DNA base compositions, and DNA reassociation values for the Candida strains studied

\begin{tabular}{|c|c|c|c|c|c|}
\hline \multirow{2}{*}{$\begin{array}{c}\text { Source of unlabeled } \\
\text { DNA }\end{array}$} & \multirow{2}{*}{$\begin{array}{c}\text { Major } \\
\text { ubiquinone }\end{array}$} & \multirow{2}{*}{$\begin{array}{c}\mathrm{G}+\mathrm{C} \text { content } \\
\quad(\mathrm{mol} \%)\end{array}$} & \multicolumn{3}{|c|}{$\%$ DNA relatedness to: } \\
\hline & & & $\begin{array}{c}\text { C. boidinii } \\
\text { CCRC } 20464^{\mathrm{T}}\end{array}$ & $\begin{array}{l}\text { C. succiphila } \\
\text { CCRC } 21410^{\mathrm{T}}\end{array}$ & $\begin{array}{c}\text { C. pinus } \\
\text { CCRC } 22437^{\mathrm{T}}\end{array}$ \\
\hline C. boidinii CCRC $20464^{\mathrm{T}}$ & Q-7 & 31.0 & 100 & 7 & 12 \\
\hline C. boidinii CCRC 21758 & Q-7 & 31.0 & 87 & 6 & 9 \\
\hline C. methylica CCRC $21757^{\mathrm{T}}$ & $\mathrm{Q}-7$ & 30.8 & 101 & 6 & 15 \\
\hline C. succiphila CCRC $21410^{\mathrm{T}}$ & Q-7 & 40.0 & 9 & 100 & 4 \\
\hline C. methanolophaga CCRC $22418^{\mathrm{T}}$ & Q-7 & 39.5 & 13 & 90 & 9 \\
\hline C. pinus CCRC $22437^{\mathrm{T}}$ & Q-7 & $37.3^{a}$ & 32 & 3 & 100 \\
\hline C. nitratophila CCRC $21583^{\mathrm{T}}$ & Q-7 & $36.6^{a}$ & 5 & 3 & 5 \\
\hline C. pignaliae CCRC $21625^{\mathrm{T}}$ & Q-7 & $42.7^{a}$ & 23 & 10 & 12 \\
\hline C. nanaspora CCRC $22419^{\mathrm{T}}$ & $\mathrm{Q}-7$ & & 13 & 11 & 5 \\
\hline C. cariosilignicola CCRC $21405^{\mathrm{T}}$ & Q-7 & $35.1^{a}$ & 30 & 8 & 11 \\
\hline
\end{tabular}

${ }^{a}$ Data from references cited by Barnett et al. (1). 


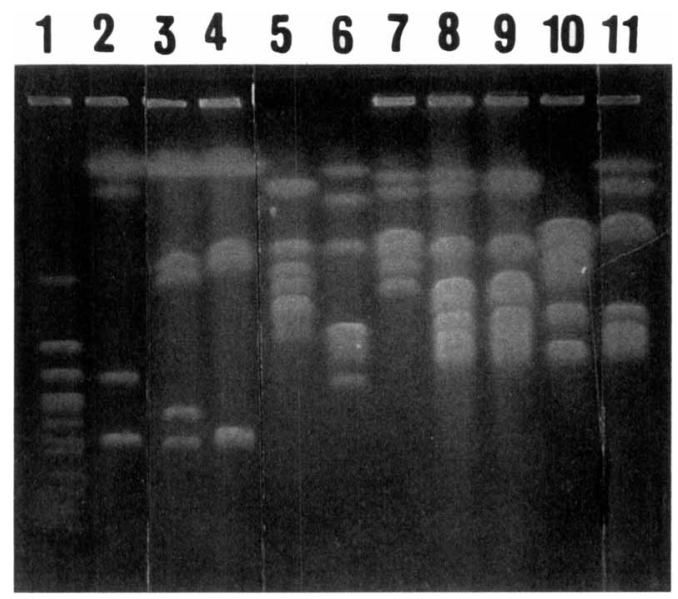

FIG. 1. Pulsed-field gel electrophoresis banding patterns of chromosomal DNAs isolated from the Candida species studied. The following conditions were used for contour-clamped homogeneous electric field analysis: hexagonal electrode array; pulse time, 60 to $200 \mathrm{~s}$ for $18 \mathrm{~h}$ and then 200 to $600 \mathrm{~s}$ for $60 \mathrm{~h}$; and a constant voltage of $100 \mathrm{~V}$. S. cerevisiae YNN 255 was used as a reference (lane 1). Lane 2, C. boidinii CCRC 20464 $4^{\mathrm{T}}$, lane 3, C. boidinii CCRC 21758; lane 4,C. methylica CCRC $21757^{\mathrm{T}}$; lane $5, C$. nitratophila CCRC $21583^{\mathrm{T}}$; lane $6, C$. pinus CCRC $22437^{\mathrm{T}}$; lane 7, C. pignaliae CCRC $21625^{\mathrm{T}}$; lane 8 , C. succiphila CCRC 21410 ${ }^{\mathrm{T}}$; lane 9, C. methanolophaga CCRC 22418 ; lane 10, $C$. cariosilignicola CCRC $21405^{\mathrm{T}}$; lane $11, C$. nanaspora CCRC $22419^{\mathrm{T}}$.

between these two species. In group II, the level of DNA relatedness between $C$. methanolophaga and the type strain of C. succiphila was $90 \%$, supporting the hypothesis that these two species are closely related. All of the species in group III exhibited low levels of DNA relatedness to the type strains of $C$. pinus, $C$. boidinii, and C. succiphila (Table 3 ).

On the basis of the results described above, we concluded that the members of each of two Candida species pairs $(C$. boidinii and $C$. methylica; $C$. methanolophaga and $C$. succiphila) do not differ significantly in their phenotypic characteristics. The organisms were also found to be closely related on the basis of ubiquinone system, DNA base composition, and DNA relatedness data. It seems reasonable to combine the members of each species pair into the same taxon. Because the names $C$. boidinii and $C$. succiphila have priority over $C$. methylica and $C$. methanolophaga, respectively $(9,11,13,17), C$. methylica is considered a synonym of $C$. boidinii, and $C$. methanolophaga is considered a synonym of $C$. succiphila.

All of the group III ( $C$. pinus, $C$. nitratophila, $C$. pignaliae, $C$. nanaspora, and C. cariosilignicola) exhibited low levels of DNA relatedness with one another, so the organisms in this group should be maintained in their original separate taxa.

We thank the Ministry of Economic Affairs, Republic of China, for financial support.

We thank I. Banno, Institute for Fermentation, Osaka, for his invaluable suggestions and T. Y. Liu and W. H. Hsu, Food Industry Research and Development Institute, Taiwan, Republic of China, for their encouragement.

\section{REFERENCES}

1. Barnett, J. A., R. W. Payne, and D. Yarrow, 1990. Yeasts: characteristics and identification, 2nd ed. Cambridge University Press, Cambridge.

2. Billon-Grand, G. 1989. Influence on minor peaks of coenzyme Q of the glucose concentration in the culture medium, the stage of the growth cycle, and the duration of the coenzyme $Q$ extraction: required conditions for determining the minor coenzyme $Q$. J. Gen. Appl. Microbiol. 35:261-268.

3. Carle, G. F., and M. V. Olson. 1985. An electrophoretic karyotype for yeast. Proc. Natl. Acad. Sci. USA 82:3756-3760.

4. Collins, M. D., T. Pirouz, M. Goodfellow, and D. E. Minnikin. 1977. Distribution of menaquinones in actinomycetes and corynebacteria. J. Gen. Microbiol. 100:221-230.

5. Ezaki, T., Y. Hashimoto, N. Takeuchi, H. Yamamoto, S.-L. Liu, K. Matsui, and E. Yabuuchi. 1988. Simple genetic method to identify viridans group streptococci by colorimetric dot hybridization and fluorometric hybridization in microdilution wells. J. Clin. Microbiol. 26:1708-1713.

6. Ezaki, T., Y. Hashimoto, and E. Yabuuchi. 1989. Fluorometric deoxyribonucleic acid-deoxyribonucleic acid hybridization in microdilution wells as an alternative to membrane filter hybridization in which radioisotopes are used to determine genetic relatedness among bacterial strains. Int. J. Syst. Bacteriol. 39:224-229.

7. Kaneko, Y., and I. Banno. 1991. Reexamination of Saccharomyces bayanus strains by DNA-DNA hybridization and electrophoretic karyotyping. Inst. Ferment. Res. Commun. (Osaka) 15:30-41.

8. Komagata, K. 1991. Systematics of methylotrophic yeasts, p. 25-37. In I. Goldberg and J. S. Rokem (ed.), Biology of methylotrophs. Butterworth-Heinemann, Boston.

9. Kumamoto, J., M. Yamamoto, Y. Seriu, K. Kouno, R. Okamoto, T. Ishikura, and A. Takamatsu. 1980. Four new species of methanolassimilating yeasts: Candida methanolophaga, Candida ovalis, Candida ooitensis and Pichia methylovora. Trans. Mycol. Soc. Jpn. 27:387-397.

10. Lee, J. D., and K. Komagata. 1980. Taxonomic study of methanolassimilating yeasts. J. Gen. Appl. Microbiol, 26:133-158.

11. Lee, J. D., and K. Komagata. 1980. Pichia cellobiosa, Candido cariosilignicola, and Candida succiphila, new species of methanolassimilating yeasts. Int. J. Syst. Bacteriol. 30:514-519.

12. Lee, J. D., and K. Komagata. 1983. Further taxonomic study of methanol-assimilating yeasts with special reference to electrophoretic comparison of enzymes. J. Gen. Appl. Microbiol. 29:395-416.

13. Ramirez, C. 1953. Estudio sobre nuevas especies de levaduras aisladas de diferentes sustratos. Microbiol. Esp. 6:249-253.

14. Saez, H., and L. Rodrigues de Miranda. 1988. Deux nouvelles especes de levure, d'origine animale, isolees au Parc Zoologique de Paris: Cryptococcus feraegula et Candida nanaspora. Bull. Soc. Mycol. France 104:213-215.

15. Sor, F., and H. Fukuhara. 1989. Analysis of chromosomal DNA patterns of the genus Kluyveromyces. Yeast 5:1-10.

16. Tamaoko, J., and K. Komagata. 1984. Determination of DNA base composition by reversed-phase high performance liquid chromatography. FEMS Microbiol. Lett. 25:125-128.

17. Trotsenko, Y. A., S. V. Bykovskaya, N. N. Kirikova, and I. P. Bab'eva. 1974. Candida methylica sp. n.--a new methanol-utilizing yeast species. Mikol. Fitopatol. 8:323-326.

18. van der Walt, J. P., and D. Yarrow. 1984. Methods for isolation, maintenance, classification and identification of yeasts, p. 45-104. In N. J. W. Kreger-van Rij (ed.), The yeasts: a taxonomic study, 3rd ed. Elsevier Science Publishers B. V., Amsterdam.

19. Vollrath, D., and R. W. Davis. 1987. Resolution of DNA molecules greater than 5 megabases by contour-clamped homogeneous electric fields. Nucleic Acids Res. 15:7865-7876. 